\title{
AZ AKADÁLYMENTESSÉG MEGJELENÉSE A SZÁLLODAHAJÓS TURIZMUSBAN A DUNA MENTÉN
}

\author{
Pókó Nikolett \\ Pécsi Tudományegyetem Közgazdaságtudományi Kar Regionális Politika és Gazdaságtan \\ Doktori Iskola,pokoniki@gmail.com
}

DOI: $10.15170 / T V T .2021 .06 .01 .07$

\begin{abstract}
Absztrakt
A turizmusban az akadálymentességgel kapcsolatos jó gyakorlatok már megjelentek, de Magyarországon az ágazat egészére még nem jellemző a komplex akadálymentesítés, a fogyatékkal élő turisták igényeinek figyelembe vétele a turisztikai infra- és szuprastruktúra, illetve a programkínálat megtervezésénél. Az óceánjáró hajók adottságai, a programok sajátossága jobb infrastrukturális körülmények kialakítását teszik lehetővé akadálymentesség szempontjából, mint a folyami szállodahajók esetében. A turizmuson belül még viszonylag új ágazatnak számít a szállodahajó turizmus és az akadálymentes turizmus is; a két ágazat együttes vizsgálatára tesz kíséretet a jelen tanulmány, egymásra való hatásuk, közös fejlesztési pontok kijelölésével. A mai gazdasági környezetben más turizmust befolyásoló tényezők is változnak, a társadalmi csoportok szerkezete és gazdasági lehetőségeik, a digitális eszközök fejlödése, a globális intermodális közlekedés új innovatív megoldásokat indukálnak.

A szállodahajós turizmuson belül egyre több figyelmet kell fordítani a marketing és az utazás lebonyolítása során az akadálymentességre, amely sem a forgalmas turisztikai célterületeken, sem a tömegturizmus által nem érintett természeti területeken nem alakult még ki igazán; nem jellemző sem a Budapest agglomerációját érintő tömegturisztikai tekintetben, sem a ritkábban lakott vidéki területeken, például ausztriai vagy bolgár ritkán Duna-szakaszokon. Az amerikai és harmadik világbeli nagyobb tömegeket megmozgató akadálymentes turizmus hulláma Európában is meg fog jelenni; a turizmusban és a szállodahajós turizmusban fel kell készülni szakmai, szolgáltatói és infrastrukturális szempontból az új jelenségre.
\end{abstract}

Kulcsszavak: szállodahajós turizmus, szállodahajók marketingje, akadálymentes turizmus, Duna 


\begin{abstract}
Good accessibility practices in tourism have already emerged, but in Hungary the sector as a whole is not yet characterised by complex accessibility, taking into account the needs of tourists with disabilities, planning tourism infrastructure and superstructure, and program offerings. Both river cruise tourism and barrier-free tourism are relatively new sectors, and the present study is an attempt for the joint study of the two sectors, their interaction, by identifying common development points. In today's economic environment, other factors influencing tourism have also changed, the structure of social groups and their economic opportunities, the development of digital devices, global intermodal transport induce new innovative solutions.

Within cruise tourism, more and more attention need to be paid to accessibility in marketing and travel, which has not yet been resolved either in mass tourist destinations or in natural areas not affected by mass tourism. The wave of barrier-free tourism, which is moving larger masses in the US and third world countries, will also appear in Europe, not only in tourism in general but in the river cruise tourism as well, professional, service and infrastructural preparation is required by the new phenomenon.
\end{abstract}

Keywords: river cruise tourism, accessibility and disabled people in river cruise tourism, Danube 


\section{Bevezetés}

Napjaink idősödő generációi, de a fiatalabb generációk is elkezdték felismerni az új trendeket, próbálnak alkalmazkodni hozzájuk, több idejük van utazni, figyelembe veszik az egészséges életmód fontosságát és annak pozitív hatásait: növekvő számban és arányban választanak olyan turisztikai szolgáltatásokat és programokat, ahol rendszeres fizikai testmozgást végezhetnek, illetve a jobb fizikai közérzet mellett szellemi frissességüket aktivizálhatják. Erre a fogyatékkal élő társainknak, közöttük is mindegyik generációnak ugyanúgy igénye van, az ő speciális igényeikre adott megoldások terén ugyanakkor még vannak komoly elmaradások. Nem kivétel ez alól a szállodahajós turizmus sem.

A szállodahajós turizmusban privát utasként megjelennek a fogyatékkal élő turisták, átlagosan 4-5 fő egy mintegy 60 fős csoportban. Egyre több szervezet támogatja ezen személyek utazását, így egységes csoportként, egyszerre nagyobb létszámban is fellelhetőek a szállodahajókon és a szállodahajók fakultatív programjain. Tehát a tendencia is azt mutatja, hogy foglalkozni kell ezzel a jelenséggel és alternatív megoldásokat kell kidolgozniuk az utazásszervezőknek és a turisztikai kínálatban közremüködő szolgáltatóknak. Az óceánjáró hajókon megjelent akadálymentes turizmus növekvő tendenciája meg fog mutatkozni néhány éven belül az európai folyami szállodahajózásban is.

Megjelentek már tanulmányok, amelyek a fogyatékossággal élő emberek utazási szokásait, lehetőségeit, turisztikai szolgáltatások általuk történő igénybevételének módját vizsgálják. Jelen tanulmány figyelembe vette az akadálymentes turizmus, az akadálymentesség szempontjainak megjelenését a vendéglátóiparban, a hotelek kínálatában, körülményeket és nehézségeket, de egyben fókuszál az óceánjárókon és elsősorban a folyami szállodahajókon felmerülő problémákra, amelyekkel a fogyatékossággal élők szembesülnek a hajózás során. A dunai szállodahajókon utazó vendégeknek számos alternatíva kínálkozik programokból, azonban a fogyatékkal élők számára még nem alakult ki széles választék: vagy csatlakoznak a programokhoz, vagy a hajó fedélzetén maradnak a kirándulás helyett.

\section{Szakirodalmi áttekintés}

Az európai uniós programok legkedveltebb kifejezései közé tartoznak a fenntarthatóság, az időskorúak védelme és a mozgásukban korlátozottak védelme, támogatása, befogadása. Elsősorban a mobilitás, mint a közlekedési feltételek javítása és az idősek társadalmi kirekesztettségének csökkentése áll a fókuszban. A fenntarthatóság elvei teret nyernek a turizmus tudományában és gyakorlatában, amelynek egyik megnyilvánulása kapcsolatban áll az akadálymentesítéssel (FARKAS, J. 2019). Az EU az akadálymentességet elsősorban a közösségi élettérben létrejövő helyváltoztatás fizikai korlátainak felszámolásaként értelmezi. Az akadálymentesítés fogalomköre messze túlmutat a fizikai élettér elérhetővé tételén, a fogyatékosság meghatározásunk már nem kielégítő, a fenntarthatóság keretei is jelentősen átértelmeződnek (FARKAS, J. - PETYKÓ, CS. 2019).

A turisztikai szolgáltatások és az akadálymentesség konkrét gyakorlatában az idegenforgalmat és az akadálymentesítést először 1980-ban, a Manilai Nyilatkozat révén említették, majd a Turisztikai Világszervezet kezdett el foglalkozni az akadálymentesítéssel. Ezeket az ajánlásokat tovább módosították, és modellként szolgálnak a fogyatékossággal élő emberek polgári jogainak védelméhez, még mindig nem beszélve a fogyatékosság és az idegenforgalom mélyebb összefüggéseiről. 
A Turizmus Világszervezete (UNWTO) kijelenti, hogy az idegenforgalmi létesítményeknek, termékeknek és szolgáltatásoknak mindenki számára elérhetőnek kell lenniük. Ennek minden felelős és fenntartható turisztikai politika középpontjában kell állnia. A turizmus mindenkinek (Tourism for all) elvével kapcsolatban az UNWTO meghatározza a turizmushoz való jog elvét és az esélyegyenlöség biztosításának fontosságát a GCET, a Turizmus Globális Etikai Kódexének (1999) 7. cikkében. A Fogyatékossággal élő személyek jogairól szóló Egyezményben a 24. cikk deklarálja mindenki jogát a pihenésre, a szabadidőre és az idegenforgalomra, a 30. cikk pedig a kulturális életben való részvétel jogát, a szabadidős és sporttevékenységekben való részvétel jogát; ezen programok helyszínének eléréséhez való jogot.

Az ENAT, az Akadálymentesített Turizmus Európai Hálózata 2006-tól müködik, célja az, hogy az európai turisztikai célpontokat, termékeket és szolgáltatásokat minden utazó számára elérhetővé tegye, és elősegítse az elérhető turizmust, az akadálymentesség iránti szélesebb körü tudatosságot és megértést az utazás és turizmus minden területén Európában. Az ENAT célja, hogy platformot biztosítson az európai idegenforgalom területén az akadálymentességgel kapcsolatos ismeretek és szakértelem fejlesztésére. Magyar tagja a hálózatnak még nincs. A megközelíthetőség és akadálymentesség fogalma több uniós dokumentumban is megtalálható, például az Európai Bizottság releváns riportjaiban (EUROPEAN COMMISSION, 2014) vizsgálják az EU tagországokat és mint turisztikai fogadó terület szempontjából az EU USA-val, Oroszországgal, Kínával és Svájccal való kapcsolatát.

Nem csak az idős korosztály a célcsoport, annak ellenére, hogy ez a legnagyobb mértékben érintett célcsoport a turizmus és akadálymentesítés kapcsolatát tekintve. Az Egészségügyi Világszervezet (WHO) becslése szerint a világ népességének 15\%-a (1 milliárd ember) valamilyen fogyatékossággal él. Az UNWTO meg van győződve arról, hogy a turisztikai létesítmények, termékek és szolgáltatások mindenki számára elérhetővé válásának minden felelősségteljes és fenntartható turisztikai politika központi elemét kell képeznie.

Az uniós és nemzetközi jogrendszeren kívül a tudományos munkákban is foglalkoztak a kutatók az akadálymentességgel. A kutatók szerint az akadálymentes turizmus megvalósulásának három fö akadálya van: a fizikai hozzáférést akadályozó tényezők, a szemléletbeli és a hozzáállással kapcsolatos problémák, valamint az információ hiánya. A fogyatékosság meghatározása már nem kielégítő, a fenntarthatóság kereteit is jelentősen újra kell értelmezni az uniós és nemzetközi gyakorlatban éppen úgy, mint a kutatásokról szóló tanulmányokban (EICHHORN, V. et al. 2008, EICHHORN, V. - BUCHALIS, D. 2011).

A turisztikai szereplők számára is fontos a fogyatékkal élő turisták turizmusának megértése, igényeik tanulmányozása a célállomás tapasztalatai és a megfelelő szállás kialakítása érdekében (BLICHFELDT, B. S. - NICOLAISEN, J. 2011, DARCY, S. 1998, 2010, 2011). A legtöbb tanulmány ugyanakkor a konkrét hotelszobával, vagy sportprogram igénybevételével foglalkozik az akadálymentesség szempontjából, azzal nem, hogy odáig milyen módon jut el az ezt a szolgáltatást igénybe vevő turista. A turisztikai ipar és a fogyatékossággal élő személyek vonatkozásában ritkák a tanulmányok, különösen a folyami hajózási turizmus területén.

A fogyatékossággal élők turisztikai tapasztalataival kapcsolatos kutatások először az 1970-es évek végén jelentek meg, és a kutatók még az 1980-as évek végén és az 1990-es évek elején is csak „kacérkodtak ezzel a kérdéssel” (McKERCHER, B. et al. 2003: 467. o.). A turizmus, a fogyatékosság és a környezeti összefüggések közötti kölcsönhatás nagyon összetett (PACKER, T. et al. 2006). Ma egyre több tanulmány foglalkozik a fogyatékossággal élők turisztikai tapasztalataival, de többségük a szállodával és a szállással kapcsolatban (LOVELOCK, B.A. 2009). A repülögépeken vagy vonatokon történő turistamozgással kapcsolatban hátrányban vannak információk és megfelelő infrastruktúra hiánya miatt a mozgáskorlátozott turisták. 
A közösségi média nagyobb esélyegyenlőséget biztosít számukra, az információk elérése érdekében az emberek hálózatokat hoznak létre, és ösztönzik a fogyatékossággal élö embertársaikat, hogy osszák meg tapasztalataikat (ALTINAI, Z. et al. 2016). Az internet és az új technológiák segíthetnek (KUHLEN, T. - DOHLE, C. 1995), hogy a fizikai fogyatékossággal élö emberek profitáljanak az innovatív virtuális valóság technikákból. Számos konkrét példa bemutatja a virtuális valóság, mint fejlett vizuális eszköz alkalmazhatóságát a különféle fogyatékosságok terápiájára és rehabilitációjára. DOMÍNGUEZ, V. et al. (2015) értéket ad a fogyatékosságnak az idegenforgalmi politikába, tervezésbe és fejlesztésbe történő beépítése terén. Ezen kívül a fejlődő országoknak politikát kellene kidolgozniuk az idegenforgalmi szolgáltatások és az intézményi szolgáltatások támogatására és a webes akadálymentesség proaktív végrehajtására.

Magyarországi viszonylatban az 1998. évi XXVI. törvény a fogyatékos személyek jogairól és esélyegyenlőségük biztosításáról kodifikálta a fogyatékos emberek jogait és azok érvényesítési eszközeit. A 2007. évi XCII. törvénnyel Magyarország elsőként ratifikálta a Fogyatékossággal élő személyek jogairól szóló ENSZ egyezményt (MEOSZ, 2016). Az Egyezmény utat nyitott a fogyatékosság új, emberi jogi értelmezésének, hiszen a korábbi közgondolkodással szemben kimondta: a fogyatékosság nem betegség, hanem a társadalmi sokszínüség része, és „,a fogyatékos személyek és az attitüdbeli, illetve a környezeti akadályok kölcsönhatásának következménye, amely gátolja őket a társadalomban való teljes és hatékony, másokkal azonos alapon történő részvételben" (Egyezmény Preambulum e) pont). Az Egyezmény 9. cikke a hozzáférhetőség címszó alatt arról rendelkezik, hogy a fogyatékos személyek számára „másokkal azonos alapon kell biztosítani a fizikai környezethez, a közlekedéshez, az információhoz és kommunikációhoz, beleértve az információs és kommunikációs technológiákat és rendszereket, valamint más, nyilvánosan hozzáférhető vagy rendelkezésre álló lehetőségekhez és szolgáltatásokhoz való hozzáférést, mind városi, mind vidéki területeken”. A 2013. évi LXII. törvény § (1) meghatározza a fogyatékos személy fogalmát. „A fogyatékosság alatt olyan tartós vagy végleges - veleszületett vagy szerzett - érzékszervi, kommunikációs, fizikai, értelmi vagy pszichoszociális károsodást, illetve ezek bármilyen halmozódását értjük, amely a környezeti, társadalmi és egyéb jelentős akadályokkal kölcsönhatásban a hatékony és másokkal egyenlö társadalmi részvételt korlátozza vagy gátolja." A fogalommeghatározásnál a fogyatékosság típusai és pontos fogalmuk is megtalálhatóak, ezek a mozgássérültség, látássérültség, hallássérültség (nagyothallás, illetve siketség), siketvakság, beszéd fogyatékosság (némaság), értelmi fogyatékosság, autizmus, többszörös fogyatékosság.

Az akadálymentesség esetén még mindig fogyatékosságra gondolnak a legtöbben (KÖNCZEI, GY. - HERÁDI, I. 2015). „Az akadálymentes turizmus a mindenki számára egyenlő módon elérhető turizmust jelenti, amely fizikai, illetve értelmi képességeiben akadályozottak számára is elérhetővé és élvezhetővé teszi az ép társadalom utazóinak kínált turisztikai szolgáltatásokat.” (MTÜ, 2017). Az akadálymentes turizmust turisztikai termékként értelmezve, a célcsoportok meghatározásánál már megjelenítik azokat a társadalmi csoportokat, akik élethelyzetüknél vagy életkoruknál fogva érintettek az akadálymentes szolgáltatások kínálatának kialakításában. Újszerü hatások is megjelennek, mozgáskorlátozottak és nyugdíjasok bevételeikből mindenképpen terveznek utazásra költeni és egyre többen, viszont a desztinációk attrakcióinak látogatását és az azzal járó kiadásokat alaposan meg kell tervezniük az utazási döntések meghozatalakor (ZSARNÓCZKY, M. 2018). A Nemzeti Turizmusfejlesztési Stratégia 2030 már hozzáférhető turizmusról beszél, melynek megvalósítását a horizontális beavatkozási területek közé emeli. Cél a fizikai és az infokommunikációs akadálymentesítés, a desztinációk könnyü megközelíthetősége, közösségi közlekedési eszközökkel vagy saját jármüvel egyaránt. Gyors, akadálymentesített hajószolgáltatást kell indítani a Dunakanyarban, mely segíti a térség turisztikai vonzerejének kihasználását. A kiemelt turisztikai fejlesztési térségek vízitúrázásra alkalmas vizein a túrázók számára fontos infrastruktúrát szintén ki kell építeni. A hajós szolgáltatásokat is integrálni kell az egységes országos utazástervező és jegyértékesítési rendszerbe (MTÜ, 2018). 
Az Erasmus projekt keretében a Peer Act projekt bemutatja a legfrissebb tanulmányt (GONDA, T. - RAFFAY, Z. 2020a) a fogyatékkal élők turisztikai magatartásáról. A szerzők 5 ország (Magyarország, Németország, Olaszország, Spanyolország és Horvátország) releváns közpolitikáját és gyakorlatát mutatják be, 23 jó gyakorlatot gyüjtöttek össze, és kérdőíves felmérést végeztek a fogyatékkal élök körében, az akadálymentes turizmus résztvevőivel. Az eredmények azt is mutatják, hogy az európai és a világ turisztikai piacai általában egyre több fogyatékkal élő utassal számolnak a turizmusban. Az egyenlő esélyü hozzáférés a turisztikai szolgáltatásokban is nagyon fontos, innovatív megoldásokat javasol (GONDA, T.- RAFFAY, Z. 2020b.).

\section{Módszertan}

Jelen tanulmány összefoglalja a fogyatékkal élők és az akadálymentesség legfontosabb jogi deklarációit világviszonylatban, azok fejlödését napjainkig. Összpontosítva a fogyatékkal élők turisztikai tapasztalataira (DARCY, S. 2009, PAGÁN, R. 2012, PORIA, Y. et al. 2009, 2010), a legtöbb tanulmány a fogyatékkal élők nehézségeit írja le a szállodában, de nem ad megoldási javaslatokat. Az akadálymentesített idegenforgalmi szolgáltatásokon túl a közlekedési nehézségekkel, idegen nyelven való kommunikációval, extra szolgáltatások költségeivel csak érintőlegesen foglalkoznak. Az egyik kutatási irány összegyüjti az összes jogalkotási szolgáltatást és a fogyatékossággal élő személyek jogait, a második a turizmusban részt vevő, fogyatékossággal élő emberek jellemzőit, valamint a fogyatékossággal élö emberek gazdasági lehetőségeit írja le, de a két témakör külön-külön szerepel az eddigi kutatásokban.

A kvalitatív módszertani megközelítések az akadálymentesített turizmus témájának egyedülálló összetettségét mutatják. A tanulmány a szakirodalom elemzésével magában foglalja az idegenforgalomról szóló szakirodalom, a nemzetközi jogi háttér, az utasszállítás és más utazási és turisztikai szolgáltatók gyakorlati helyzetének és jelenlegi gyakorlatának vizsgálatát. Meghatározó vizsgálati eredményeket közöl a közösségi média tartalmak elemzésével, illetve a szerző közvetlen tapasztalatával.

Megfelelö adatok hiányában a legtöbb kutatási megközelítés ad-hoc vizsgálatokon alapul, kiragadva egy-egy utas véleményét, vagy 10-15 fös, nem reprezentatív mintavételen alapuló kérdőíves elemzésre. A tanulmány a szerző 15 éves idegenvezetői tapasztalatait és a közösségi médiából származó, a folyami hajózásról szóló cikkekről (pl. FORBES, 2017), óceánjárókról és folyami hajókról szóló weboldalakról, a fogyatékossággal élő emberekkel kapcsolatba lépő turisztikai online hálózatokról, valamint a folyami szállodahajózásról származó információkat tartalmazza.

Az interneten keresztül a fogyatékossággal élők több lehetőséget kapnak, hogy nyilatkozzanak személyes tapasztalataikról, a fogyatékossággal élő világutazók könyveket írtak az óceánjárókon szerzett extrém tapasztalataikról, arra ösztönözve a többi embert, hogy utazzanak bátran, de egyben figyelmeztetve is őket arra, hogy mire figyeljenek az utazás tervezése és lebonyolítása során. Sőt, ez a kutatási megközelítés lehetővé teszi a szerző számára, hogy megemlítsen emlékezetes pillanatokat a fogyatékossággal élő személyekkel a folyami szállodahajós turizmusban, valamint a nem hivatalos interjúkon, a fogyatékkal élő turistákkal vagy a folyami hajóút személyzetével folytatott személyes beszélgetéseken keresztuil. Ez a megközelítés magyarázatot adhat arra, hogy bizonyos szolgáltatásokat, szabadidős létesítményeket vagy fakultatív kulturális programokat miért nem említettek korábbi tanulmányok. 
Több ezer komment átnézése után, néhány leggyakrabban előforduló kérdésre és válaszra példa (Tripadvisor, Cruises Forum, CruiseCritic, Travelweekly):

„Szüleim a múltban számos körutazáson vettek részt, anyukámnak azonban most mobilitási problémái vannak. Tudna valaki ajánlani egy kerekesszék-barát vagy mozgáskorlátozottakat kiszolgáló hajóutat / hajót?”

„Sok hajókirándulást elözetesen kerekesszék-barátként értékesítenek, majd csalódás a vége. Ne támaszkodj arra, amit a hajó mond neked. A Sage Traveling-et ajánlom."

„Nincs lábam, ezért mindig kerekesszékhez vagyok kötve. Kétszer jártam a Celebrity Cruises-zel (Infinity és Eclipse), és kiválónak találtam, segitőkész személyzettel és speciálisan szervezett kirándulásokkal, és voltak rámpák és felvonók. A fürdöszobában a kevés hely gondot okozhat, de bérelhetsz felszereléseket a Mobility at Sea-töl."

„Helló, Howard, ugyanabban a korosztályban vagyunk, és mivel a feleségem mozgáskorlátozott, sok folyami hajóúton jártunk, és kevés óceánjárón. Néhány hete a Rajnán voltunk a barátokkal, együtt ünnepeltük a születésnapunkat a hajón.”

„Sokat utaztam a szolgálati segítö kutyámmal, belföldön és nemzetközi viszonylatban. A kutyát szállító dobozban lehet utaztatni, de oda helyezték, ahol az utasok dohányoztak, és mindig találtam cigarettacsikkeket a kutya szállitó dobozában. A hajó vezetöjének elmondtam nemtetszésemet és 15\% -os kedvezményt kínáltak egy jövöbeli hajóútra!"

„,WOWOWOW ROZ! Olyan informativ és segitőkész vagy! Nincs szolgálati segítő kutyám, de vannak barátaim, akiknek van ... talán meg tudom győzni őket, hogy jöjjenek el egy hajózásra! ;)”

Ezek a források azért fontosak, mert a tanulmányok sem tárták fel azokat a problémákat, amelyek néhány komment olvasása után egyértelművé teszik a mozgásukban korlátozott utasok alapvető igényeit. Ilyen igények a motorizált önjáró kerekesszék bérlése, kölcsönzése, a speciális segédeszközök súlykorlátozása és elhelyezhetőségük a hajón vagy a kabinokban. Hiányos a kölcsönözhető speciális eszközök listája, amelyeket a hajó is tudna biztosítani, vagy olyan speciális eszközöket kölcsönző cégek elérhetősége, akikkel a hajó kapcsolatban áll. A szolgálati segítö kutyával való utazás szabályai sem kiforrottak, a hajón utazók sem tudják, hogyan viselkedjenek ilyen kutyákkal és a velük érkező utastársakkal.

\section{Akadálymentesség a szállodahajós turizmusban}

A fogyatékossággal élő személyek jogosultak a folyami hajózási turisztikai tevékenységekre, szolgáltatásokra. Megjelentek a témában útikönyvek, amelyek buzdítják a turistákat, hogy utazzanak, abban az esetben is, ha akadálymentességre lenne szükségük (LONGMIRE, S. 2020).

A szállodahajós turizmuson belül egyre erőteljesebben jelenik meg a mozgáskorlátozottak igénye a folyami szállodahajós utazásra. Több kutatás és vizsgálat is megállapította, hogy szállodahajós utazásokon elsősorban a 60-70 év feletti korosztály vesz részt, közöttük sok a mozgáskorlátozott.

Akik bottal vagy kerekesszékkel indulnak egy fakultatív programra, sokkal több hátrány éri őket, mint nem mozgáskorlátozott utastársaikat, például a helyi terepviszonyoknál. Egy városnézésnél, macskaköves utcán, vagy a kiemelt városi látnivalók esetében, a tömegben nem tudnák követni a csoportot és nem tudnák élvezni a látottakat, vidéki terepviszonyok között alig jutnának pár méterre, főleg nem a rendelkezésre álló időn belül. A járdák, gödrök, útpadkák, egyéb egyenetlen terepviszonyok megnehezítik a közlekedést. 
A legtöbb luxus szállodahajó biztosít elektromos kerékpárokat, hogy a gyaloglás idejét lecsökkentse, de a vidéki élményt mégis biztosítsa. A mozgáskorlátozott csoportoknak kifejezetten kisvonatos városnézést szerveznek, ugyanazt látják szinte a városból, idegenvezetővel kísérve, mint a nem ,gentle walker” társaik. Ha tovább szeretnének tartózkodni bizonyos helyszínen, a szállodahajó külön részükre shuttle buszt müködtet. A motorizált önjáró kerekesszékek használatára sem a hajón, sem a hajó által szervezett fakultatív programokon nincsen kiforrott gyakorlat.

Ha akadálymentességre gondolunk, gyakran a bot vagy a kerekesszék jut eszünkbe, de igen sok siket és siketnéma külföldi is jár a szállodahajókon Magyarországra is. Számukra még különlegesebb megszervezni a városnézéseket, fakultatív programokat. Velük általában két jeltolmács is utazik, akik félóránként váltva egymást, segítik a csoport és a csoporton kívüliek kommunikációját.

A fogyatékossággal élő utazók és segítőik akadálymentes életfeltételeinek biztosítása szükséges a hajókon, de sokszor még plusz költség felszámításával sem megoldhatóak, a hajó méreteiből adódó infrastrukturális hiány miatt, vagy mert még nem gyártottak szállodahajókat az akadálymentesség szempontjainak figyelembevételével. Háziállatok felvitele a fedélzetre tilos, de a szolgálati segítő kutyával érkező utasok számára lehetséges. Mivel ennek a gyakorlata sem alakult még ki, sem a speciális igényü mozgáskorlátozottak megfelelő ellátásának gyakorlata a hajón, illetve a hajút programjain, a szolgáltatóknak sürgősen válaszokat és megoldásokat kell találniuk.

A turizmus új kihívása, hogy a szállodahajós turizmuson belül milyen kínálat alakul ki az akadálymentességet igénylő vendégek számára, a növekvő kereslet hatására például milyen budapesti és vidéki programokon tudnak részt venni Magyarországon vagy külföldön, a Dunán hajózva. Ezen a téren a Duna által érintett országokhoz képest a magyar kínálatban nagyon jó példák és jó gyakorlatok találhatóak már most is, akár a lovas programok esetében a lódobogás, a kocsikázás, a természetközelség megélése nagy élmény, de egy boros pince látogatása sem akadály már több helyszínen.

A hajón, vagy a hajózás során érintett fakultatív programok helyszínein az akadálymentesítés nehéz, mert már megépített épületek utólagos átépítése, amelyeket nem ilyen szempontból terveztek, múemlékvédelmi vagy statikai szempontból egyszerüen nem lehetséges, ezért szükségvagy félmegoldások születnek például a sok lépcsőzés elkerülésére.

A hajó személyzete mindig kiemelt figyelemben részesíti és segíti a mozgásukban korlátozott vendégeket, de nem lehet elvárni a személyzettől, vagy adott programnál, hogy plusz ember kísérje öket, főleg, ha szoros a programidő és egyszerre 4-5 busznyi, akár buszonként 60 fös csoportot kell menedzselni egy adott helyszínen. A folyami hajózási politika kiemeli, hogy a fogyatékossággal élö embereket egy olyan személynek kell kísérnie, aki segíti őket a hajón és azon kívüli utazás során, és akár 24 órában rendelkezésre áll.

Az Easy Access Travel volt az első olyan utazási ügynökség, aki speciális igényű mozgáskorlátozottaknak csoportos hajóutat szervezett. 2012 decemberében amputáltak számára szervezett hajós körutazást a Royal Caribbean és az International Liberty of the Seas fedélzetén. Volt olyan alkalom, hogy egy hónapban 91 speciális igényü mozgássérült, amputált, multiplex sclerosisban egyéb gerincbetegségben szenvedők karibi tengeri utazását szervezte meg. 
Utazásszervező ügynökségek és hajós társaságok vezetői elismerik a folyami hajóutak már meglévő szolgáltatásait a fogyatékkal élő utasok számára, de tudják, hogy a hajóút közbeni megállók és partraszállások alkalmával sok kihívással kell még szembenézniük, hogy problémamentes utazási élményt biztosítsanak a vendégeiknek. „Olyan beszállítókra van szükség, akik akadálymentesített kisbuszokat, kerekesszékes felvonókat és rámpákat tudnak biztosítani” (Trawelweekly). Az AmaWaterways már teljesen mozgáskorlátozott-barát szobát kínál, széles bejárattal, biztonsági megoldásokkal a fürdőszobában. A CroisiEurope fedélzeti speciális tereket, lifteket alakított ki. Az Avalon és a Tauck nem tud összecsukható kerekesszéket és motorizált kerekesszéket biztosítani, sem külön személyzetet a mozgáskorlátozott vendégeknek, ezért arra kéri az utasokat, hogy mindenképp kísérővel utazzanak. Az Amras Cruises Silver, Silver II és Diamond hajója a teljes fedélzeten biztosítja az akadálymentes közlekedést és elérési útvonalakat, kivéve a napozóteraszt, amelyet így nem lehet megközelíteni lifttel sem. Az Emerald Waterways képviselöje is a kikötők kialakításának infrastrukturális hiányosságaira hívja fel a figyelmet. Európában a folyami hajózásnál a vízszint, a hidak gyakorisága korlátozza a hajók fizikai méretét, így a hajók egymás melletti kikötését, az utasok átkelését, ki- és beszállítását. A legtöbb szállodahajó büszkén hirdeti, hogy rendelkezik akadálymentes megoldásokkal a fedélzeten, liftekkel, akadálymentes nyilvános terekkel, akadálymentesített WC-vel, akadálymentesített kabinokkal, speciális kapaszkodókkal a hajón és a kabinokban, speciális ágyakkal, segélyhívó gombokkal, vagy mini hütőszekrénnyel inzulin vagy más gyógyszerek tárolására, sőt készséges a személyzete a mozgáskorlátozott utasokkal - mégis mindez még sok fejlesztést kíván ahhoz, hogy valóban teljesen akadálymentesen utazhassanak azok, akiknek mozgáskorlátozottságuk miatt speciális igényeik merülnek fel.

\section{Az akadálymentes turizmus és szállodahajós turizmus összekapcsolásának lehetőségei, eredmények}

A Dunát érintő fő hajójáratok 4-15 napos utakat kínálnak Budapesttől Amszterdamig a Rajnát és a Majnát is érintve, országokat, fövárosokat, völgyeket vagy folyókanyarok vidékét bemutatva az arra járóknak. Ezeken a szakaszokon közlekednek a legnagyobb és legmodernebb két- és háromszintes folyami szállodahajók. Franciaország és Portugália korlátozottan szerepelnek az útvonalakon, itt a szállodahajón töltött út rövidebb és a fedélzeti idő is kevesebb, miközben az utazással érintett főbb turisztikai látnivalók is közel vannak egymáshoz. A szőlőtermő területek alkalmasak arra, hogy a fogyatékkal élö utasok is ellátogathassanak ide, de foglalás elött néhány információ egyeztetésére szükség van a megfelelő intézkedések előkészítésére. A Shearings utazásszervezővel a 100 utast szállító MS Alegria hajó az egyetlen, amely teljesen akadálymentes létesítményeket kínál, a hollandiai rajnai vízi hajókon utazásonként 10 mozgáskorlátozott számára lehet szobát biztosítani. A termek széles ajtói megtalálhatók az AmaWaterways hajóin, speciálisan kialakított kabinokkal, módosított fürdőszobákkal, mozgáskorlátozott utasoknak megfelelően. Az A-Rosa, CroisiEurope és Scenic hajók korlátozottan hozzáférhető szobákkal rendelkeznek, az Avalon hajók akadálymentesek, de a kabinok nem. Az Emerald Waterways hajóknak egy akadálymentesített kabinja van a recepció mellett, ajánlott az összecsukható kerekesszék, és meg kell oldani a gondozó vagy kísérő kérdését, mert a személyzetből erre a feladatra kijelölni valakit nincsen lehetőség, kapacitás. A Vikingnek nincs kijelölt akadálymentesített helyisége, de a hajók megközelíthetőek a partról. A Uniworld nem rendelkezik kerekesszékkel megközelíthető kabinokkal. A Vantage hajóknak mozgássérült kabinja és akadálymentesített mellékhelyisége van.

Nagyobb és kisebb szállodahajókat müködtető társaságok speciális kabinokat és szolgáltatásokat kínálnak fogyatékkal élő vagy kerekesszékes utasok számára, de kevés információ áll rendelkezésre arról, hogy az őket kísérők milyen ellátásban részesülnek. Úgy tünik, hogy minden szállodahajó szép és fényüző, de a fedélzetekről a képeken kívül kevés információ található. 
A szállodahajók reklámfotóin gyönyörü panorámás, erkélyes hajók láthatóak a leglátványosabb helyeken, a Rajna és a Duna menti, UNESCO által is elismert helyszíneken. Az európai sétahajózási utak történelmi és természeti helyekre, szőlőterületekre, múzeumlátogatásokra, helyi kulturális látnivalókhoz viszik a csoportokat, ahová a fogyatékkal élöknek nehezebb az eljutásuk. Különösen a Viking és az AmaWaterways minden nagyvárosban központi helyen köt ki és innen mini transzfereket biztosítva juttatják el akadálymentesen azokat az utasokat az adott programokra, akik ezt igénylik. Nem csak a mozgáskorlátozottak választják a kiadott programterv helyett a kávézás lehetőségét egy szép helyen, a vízparton, az utasok előszeretettel választanak békés, nyugodt kisvárosi helyszínt, ahol gyönyörködhetnek a táj szépségében, esetleg bepillantást nyerhetnek a helyiek életébe. Lehetőség van arra is, hogy több időt töltsenek az utasok a hajó fedélzetén. Hosszabb, egész napos programok esetén gyakran autóbuszos utazást is igénybe kell venni. Az autóbuszok nem alkalmasak kerekesszékkel való utasok szállítására hosszabb távon, a személyzet tagjai vagy más utasok azonban szívesen segédkeznek és kezet nyújtanak a buszról, vagy hajóról való fel- és leszállásnál.

A fogyatékkal élő személyek szállodai ellátásáról végzett kutatások alapján feltételezhetünk hasonlóságokat a folyami hajózási turizmus vonatkozásában is. Mivel a fogyatékkal élő vendégek gyakran más kontinensekröl érkeznek, néhány éjszakát a szállodában kell tölteniük, mielőtt hajóra szállnának, vagy elhagynák a hajóút végén az adott országot vagy kontinenst végleges hazautazásuk előtt. Ami a Dunát illeti, a harmadik országokból érkezők hajózás előtt vagy után néhány extra napot töltenek többnyire Prágában vagy Budapesten. Tehát a fogyatékkal élők számára nyújtott szállodai szolgáltatásokat ebben az esetben is vizsgálni kell a szárazföldön is. A folyami hajózási társaságok weboldalain azonban néhány információ áll csak rendelkezésre a hajózás előtti és utáni szállásokról, de a hajózás során igénybe vehető kabinokról is. A kabin méretét és felszereltségét elsősorban az árak szempontjából mutatják be. A folyami szállodahajók kabinjai sokkal kisebbek, mint a szállodai szobák, néhány módosított mellékhelyiség széles ajtókkal és felszereléssel áll rendelkezésre a fogyatékkal élők számára. A hajójáratok többsége elöírja, hogy az utasoknak összecsukható kerekesszékeket kell magukkal hozniuk. A hajók közel 20\%-a rendelkezik lifttel, 5\%-a akadálymentesített lifttel, a folyosók tekintetében a legtöbb hajó akadálymentes teljesen. Ha az akadálymentességet a teljes hajó fedélzetére vonatkoztatjuk, akkor nem csak a hajó közösségi tereire és a szobákra kell gondolnunk, hanem az egész hajótest bejárhatóságára a fedélzettel együtt. Egy-egy hajó kivételével a legtöbb esetben nem megoldható, hogy a földszintről a fedélzetre és a tetőteraszra eljussanak akadálymentesen a vendégek. A hajó fedélzetére lépcsők vezetnek, ami akkor is balesetveszélyes, amikor egy pontonhídra több hajó is kiköt egymás mellé, és az utasoknak az egymás mellé parkoló hajókon keresztül kell átvergődni a kikötő partjáig, vagy onnan vissza. Az infrastruktúra még nem megoldott akadálymentesség szempontjából, az alternatív megoldások ellenére sem, amikor két matróz a karjaiban visz ki egy idős hölgyet a partra, hogy csatlakozzon a csoporthoz, hiszen ezt az utat egyedül nem lenne képes megtenni. A fakultatív és a napi kirándulásokat részben a folyami hajózási részvételi díj, vagy programcsomag tartalmazza, a fogyatékkal élőknek külön pénzt kell fizetniük vagy segítséget igénybe venniük, ha csatlakozni akarnak a hétköznapi utasok számára biztosított kirándulásokhoz.

Azoknak, akik bottal vagy kerekesszékkel indulnak a szabadon választható programokra, fontos tudniuk, hogy milyen terepviszonyokra számíthatnak például Révbérpusztán, Solton vagy Lajosmizsén; hogy homokos talajjal, vagy kavicsos, esetleg sáros sétálótérrel találkozhatnak, amely megközelítése még a nem fogyatékkal élők számára is nehéz. A kerekesszékes emberek egyik elönye, hogy az első VIP sorból láthatják a bemutatót, az első sorban a legkényelmesebb éttermi helyen terítenek nekik az étkezésekhez. Ha az idősebbek a nyári nagy hőség miatt, vagy a fogyatékkal élők hosszabb ideig óhajtanak tartózkodni egy adott helyen, a szervezők transzferbuszt üzemeltetnek számukra, pl. a Viking vagy AmaWaterways társaságok. 
A turisztikai új kihívások között a legfontosabb a fogyatékkal élök szállodahajós útjain az infrastruktúra, e nélkül nem jöhetne létre az utazás. A fakultatív programok során alternatív technológiákat vagy virtuális technikákat is alkalmazni kell. A Duna menti országokkal összehasonlítva a magyar ajánlatok között már nagyon jó példák és jó gyakorlatok vannak, föleg a természethez oly közel álló lovasbemutatók, kocsikázások, lovaglási programok esetében, de néhány borospince meglátogatása esetén is például a Lázár Lovasparkban (Domonyvölgy).

Az első táblázat DARCY (1998) szerint mutatja be az akadálymentesség szempontjából a hozzáférés dimenzióit. A támogatási igények szintje is leírható: független (nincs támogatási igény); alacsony; közepes; magas; nagyon magas (24 órás támogatást igényel). A táblázat megmutatja, milyen szolgáltatásokra lenne igény az akadálymentesség szempontjából a szállodahajókon (DARCY, S. 1998, 2010, 2011). Egy kerekesszékes világutazó, LONGMIRE (2020) saját tapasztalatairól mesél útikönyvében, amelyet 20 szállodahajós utazásból 16-on mint kerekesszékes turistaként élt át egészen a fedélzetre jutástól az út végi kikötésig és partraszállásig.

\section{1. táblázat Az akadálymentes elérhetőség dimenziói}

\begin{tabular}{|c|c|c|}
\hline Szempontok & $\begin{array}{l}\text { Támogatási igény } \\
\text { szintje }\end{array}$ & Gyakorlati példák \\
\hline 1. Mobilitás & független, alacsony & $\begin{array}{l}\text { séta, kerekesszék, minibusz, transzfer } \\
\text { busz, vonat, repülő }\end{array}$ \\
\hline 2. Vizuális megjelenés & alacsony, közepes & vizuális megjelenés, információk \\
\hline 3. Hang, hallás útján & közepes, magas & $\begin{array}{l}\text { idegenvezető, audio-guide, } \\
\text { idegennyelvek, tolmácsok, bemutatók }\end{array}$ \\
\hline 4. Kognitív/tanulás & közepes, magas & $\begin{array}{l}\text { helyszínen megélt élmény, tapasztalat, } \\
\text { közel a természethez, közös tevékenység } \\
\text { pl. éneklés, néptánc, felfedezés öröme }\end{array}$ \\
\hline 5. Mentális egészség & $\begin{array}{l}\text { magas, nagyon } \\
\text { magas }\end{array}$ & pihenés, aktív kulturális programok \\
\hline $\begin{array}{l}\text { 6. Érzékenység, speciális } \\
\text { esetek }\end{array}$ & $\begin{array}{l}\text { magas, nagyon } \\
\text { magas }\end{array}$ & $\begin{array}{l}\text { lélegeztető segítségnyújtás, } \\
\text { élelmiszeripari vagy vegyipari } \\
\text { érzékenységek, egyéb egészségügyi } \\
\text { segítségnyújtás }\end{array}$ \\
\hline
\end{tabular}

Forrás: DARCY, S. 1998, 2010, 2011 alapján saját szerkesztés

A második táblázat megmutatja, milyen szorosan egymásra épülő szolgáltatásokra és infrastrukturális fejlesztésekre lenne igény az akadálymentességet figyelembe véve. 


\section{2. táblázat: A szállodahajós szolgáltatások és az infrastrukturális felszereltség összefüggései} az akadálymentesség szempontjából

\begin{tabular}{|c|c|}
\hline & \\
\hline $\begin{array}{l}\text { A személyek szállítását a hajótól az adott } \\
\text { desztinációba általában a hajós társaság } \\
\text { megszervezi, de ez extra szolgáltatásnak is } \\
\text { minősülhet, amelyért külön fizetni kell. Szükséges } \\
\text { a szakmai személyzet, akik tudnak foglalkozni } \\
\text { fogyatékkal élő utasokkal, problémáikkal. } \\
\text { A fogyatékkal élő turisták mindig hálás } \\
\text { köszönetnyilvánítást fogalmaznak meg a } \\
\text { szállodahajó alkalmazottainak irányukban } \\
\text { tanúsított segítőkészségükért. Kevésbé tudják } \\
\text { ugyanakkor kimutatni, hogy nem szeretik, ha az } \\
\text { emberek, más utastársak, sajnálkozva néznek } \\
\text { rájuk, egyenlőnek szeretnék érezni magukat a } \\
\text { többi utashoz hasonló bánásmóddal. }\end{array}$ & $\begin{array}{l}\text { Szállítás, közlekedés: transzfer repülőtérről és } \\
\text { vissza (akár közvetlenül a repülőtérről a } \\
\text { szállodahajóhoz), kerekesszéket is szállítani képes } \\
\text { járművekkel. } \\
\text { Hotel és szállodahajó szobákon kívüli egyéb terek } \\
\text { akadálymentes megközelíthetősége, megfelelő } \\
\text { hely a közlekedésre, akár megfordulásra. } \\
\text { Technikai segítség és speciális kiegészítők, } \\
\text { berendezési tárgyak fogyatékkal élők számára, pl. } \\
\text { fürdőben szék, alacsonyra épített zuhanyzó, } \\
\text { megfelelő beépítésủ mosdó, hajszárító, törölköző } \\
\text { tartó, szekrénypolcok... }\end{array}$ \\
\hline $\begin{array}{l}\text { A programok szabadidős tevékenységet is } \\
\text { magukban foglalnak, például városnézés, } \\
\text { természeti tájon tett kirándulás, csónakázás. Az } \\
\text { adott látogatás sikerét döntheti el a rámpák } \\
\text { megfelelő elhelyezése, mosdók elérhetősége, } \\
\text { színpadok és lelátók, ajándékboltok } \\
\text { megközelíthetősége. Fogyatékkal élő utasok } \\
\text { gyakran VIP helyet kapnak az első sorba. }\end{array}$ & $\begin{array}{l}\begin{array}{l}\text { Nehezen megközelíthető } \\
\text { épületekhez kialakított ék és járdák - } \\
\text { korlátok. }\end{array} \\
\text { Fogyatékkal élők, rék, rámpák, } \\
\text { nehezen megközelíthető esemének fizikailag } \\
\text { kültéri helyszíneken, ahol homokos, kavicsos } \\
\text { talajon kell áthaladni. }\end{array}$ \\
\hline $\begin{array}{l}\text { Elérh } \\
\text { akadá }\end{array}$ & $\begin{array}{l}\text { lmazott, írott tájékoztatás } \\
\text { számára. }\end{array}$ \\
\hline $\begin{array}{l}\text { A sz } \\
\text { kell, } \\
\text { külö } \\
\text { a he }\end{array}$ & $\begin{array}{l}\text { syatékkal éló utasok } \\
\text { tatóra lenne szükség } \\
\text { észéről. }\end{array}$ \\
\hline $\begin{array}{l}\text { Érdeklődés felkeltése az információs technológiai } \\
\text { eszközök és a szociális média használata iránt a } \\
\text { fogyatékkal élők mobilitásának ösztönzése } \\
\text { érdekében, pl. nyitott „hajózási napló”, kisfilmek } \\
\text { arról, ahogyan akadálymentesen használják } \\
\text { utasok a szállodahajó fedélzetét. Hozzáférés a } \\
\text { megfelelő akadálymentes szolgáltatásokhoz. }\end{array}$ & $\begin{array}{l}\text { A hajókirándulásokhoz kapcsolódó sport- és } \\
\text { egyéb tevékenységek előnyei az ép és fogyatékkal } \\
\text { élő utasok számára egyaránt elérhetőek. A } \\
\text { hajózáson való részvétel motiválja a fogyatékkal } \\
\text { élőket, hogy fejlesszék személyiségüket. Ehhez } \\
\text { szükséges megfelelö technikai környezet a hajó } \\
\text { fedélzetén. }\end{array}$ \\
\hline & , ha az \\
\hline
\end{tabular}

Forrás: saját szerkesztés, DARCY, S. (1998, 2010, 2011), LONGMIRE, S. (2020)

Kihívást jelent a turisztikai szolgáltatók számára, hogy kielégítsék a fogyatékkal élők és speciális turistacsoportok speciális igényeit. A közlekedés a fö korlátozó tényező, mind a hajón, mind pedig a hajóhoz való eljutásban. A fogyatékkal élők között megkülönböztethetünk mozgássérülteket (életkortól függetlenül), hallássérülteket, látássérülteket és más fogyatékkal élőket, akiknek speciális szolgáltatásokra vagy infrastruktúrára van szükségük utazásaik során. Az Alsó-Duna térségében Magyarországtól délkeletre, de Magyarországon is megtalálhatóak olyan régi épületek, amelyek pénzügyi támogatás nélkül nem lesznek alkalmasak fogyatékkal élők látogatására. 
A szállodák, vagy néhány posztkommunista épület akadálymentességét illetően tipikus hibák fordulhatnak elö, pl. rámpa vezet a bejárathoz, de dőlésszöge meghaladja a törvény által elöírt 5\% -ot, ezért túl meredek ahhoz, hogy a kerekesszéket használó személy egyedül használhassa. Valamikor már a bejárati ajtó infrastrukturális megoldása sem megfelelő egy fogyatékkal élő személy számára. A szállodahajók a szabályok miatt nem tudnak nagyobb helyiségeket kialakítani, a szobákat és az erkélyeket viszont akadálymentesebbé, hozzáférhetőbbé lehet tenni, mivel egyes felületek nagyon csúszósak. A csökkent mozgásképességű emberek gyakran szembesülnek azzal a helyszínen, hogy az akadálymentesnek hirdetett szolgáltatás nem akadálymentes. A mozgáskorlátozottak részére már megjelentek átalakított autók vagy kerekesszékek kézi vezérlésre átalakítva. Egyes helyeken már van lehetőség autó vagy csónak bérlésére mozgáskorlátozottak számára, emelőszerkezettel.

\section{Következtetések}

A folyami körutazás-szolgáltatóknak akadálymentesítési stratégiákat kell kezdeményezniük a mozgássérült turisták közlekedésének, létesítményeinek és környezeti helyzetének kezelésére. Szakképzett személyzet segítséget nyújtana a mozgássérült turisták számára a hajós utazás során. A jövőbeli kutatásoknak kifejezetten tanulmányozniuk kellene a folyami szállodahajókon a fogyatékossággal élő személyek akadálymentességgel kapcsolatos problémáit, közlekedési akadályait a mobilitás növelése érdekében. Az idegenforgalmi szolgáltatóknak fel kell ismerniük, hogy hozzanak létre olyan új turisztikai csomagajánlatokat, amelyek nem csak az időseket szólítják meg, annak ellenére, hogy az idegenforgalommal és az akadálymentességgel való találkozás szempontjából ők a leginkább érintett célcsoport. A kereslet és a kínálat egyre összetettebb és változatosabb lesz, a szállodai és folyami hajó tulajdonosok, az utazásszervezők mindig megpróbálnak megfelelőbb környezetet teremteni az új turisztikai élmények számára, és nagyon változatos termékpalettákat kínálnak az utazók számára. A hozzáférhető szolgáltatásokat igénybe vevő turisták száma folyamatosan növekszik (DANIELS, M. J. et al. 2005), az akadálymentes megközelítés piaci előnyt jelenthet. Átlagosan minden második fogyatékkal élő vendég útitárssal utazik. A föszezonon kívül az idősek és a fogyatékkal élők utószezonban is utazhatnak, különösen, mivel ezek az időszakok kevésbé mozgalmasak, az utazók ilyenkor gyakran jobban hozzáférhetnek a szolgáltatásokhoz.

A fogyatékkal élők szállodai tapasztalatai alapján feltételezhetünk hasonlóságokat a folyami hajózás akadálymentesítési igényeiben. A tanulmány akadálymentesség szempontjából a kerekesszékesekre, vagy mankót, botot használókra, a siketekre, gyengénlátókra is kitér, akadálymentességet a szállodahajókon ugyanis nem csak a nyugdíjas turisták igényelnek. Az akadálymentesség fogyatékossággal élő embertársaink alapvető joga, akik ugyanolyan jogokkal rendelkeznek az utazáshoz és a turizmus megtapasztalásához, mint nem fogyatékossággal élő embertársaik. Számos kifejezést tisztázni kell angolul és magyarul is annak érdekében, hogy megfelelően megfogalmazzuk az idegenforgalmi szakma számára alkalmazott, vagy alkalmazandó kifejezéseket. Mivel megjelent az akadálymentesség és a turizmus összevonásával foglalkozó uniós szervezet, így már elmondhatjuk, hogy EU szinten is kiemelt szerepe van e két terület összekapcsolásának. 


\section{Irodalomjegyzék}

ALTINAI, Z. et al. (2016): The Role of Social Media Tools: Accessible Tourism for Disabled Citizens. Educational Technology \& Society, 19 (1), 89-99.

BLICHFELDT, B. S. - NICOLAISEN, J. (2011): Disabled travel: Not easy, but doable. Current Issues in Tourism, 14(1), 79-102.

DANIELS, M. J. et al. (2005): "Travel Tales": An interpretive analysis of constraints and negotiations to pleasure travel as experienced by persons with physical disabilities. Tourism Management, 26(6), 919- 930.

DARCY, S. (1998): Anxiety to Access: The Tourism Patterns and Experiences of New South Wales People with a Physical Disability. Sydney, Australia: Tourism New South Wales.

DARCY, S. (2010) Inherent complexity: disability, accessible tourism and accommodation information preferences. Tourism Management 31(6):816-826. DOI: 10.1016/j.tourman.2009.08.010

DARCY, S. - DARUWALLA, P.S. (2002): Inclusive special event planning for people with disabilities. In: Harris, R. and Allen, J. (eds.): Regional Event Management Handbook. The Australian Centre for Event Management (UTS) and the Department of Industry, Science and Resources, Sydney, pp. 91-103.

DARCY, S. - DICKSON, T. (2009): A whole-of-life approach to tourism: the case for accessible tourism experiences. Journal of Hospitality and Tourism Management 16(1), 32-44. DOI: 10.1375/jhtm.16.1.32

DARCY, S. (2010): Inherent complexity: Disability, accessible tourism and accommodation information preferences. Tourism Management, 31(6), 816 - 826.

DARCY, S. (2011): Towards strategic intent: Perceptions of disability service provision amongst hotel accommodation managers. International Journal of Hospitality Management, 30(2011), 468 - 476. DOI: 10.1016/j.ijhm.2010.09.009

DOMÍNGUEZ, V. et al. (2015): Competing for the disability tourism market - a comparative exploration of the factors of accessible tourism competitiveness in Spain and Australia. Tourism Management, 47(1), 261-272.

EICHHORN, V. - BUCHALIS, D. (2011): Accessibility - A Key Objective for the Tourism Industry. In: Buhalis, D. - Darcy, S. (eds.): Accessible Tourism: Concepts and Issues. Channel View Publications, Bristol. pp. 46-61

FARKAS, J. (2019): Az akadálymentesítés primátusa a turisztikai termékfejlesztésben. In: Irimiás A. - Jászberényi M. - Michalkó G. (szerk.): A turisztikai termékek innovatív fejlesztése. Akadémiai Kiadó, Budapest. pp. 146-156.

FARKAS, J. - PETYKÓ CS. (2020): A fogyatékosság, az akadálymentesség és a mobilitás, mint egzisztenciális alaptulajdonság, TURISZTIKAI ÉS VIDÉKFEJLESZTÉSI TANULMÁNYOK $5: 4$ pp. 43-55., 13 p. (2020) DOI: 10.15170/TVT.2020.05.04.03.

GONDA, T. - RAFFAY, Z. (2020): Az akadálymentes turizmus innovatív jó gyakorlata. Modern Geográfia 2020/IV. pp. 1-14. ISSN: 2062-1655 DOI: 10.15170/MG.2020.15.04.01

GONDA, T. - RAFFAY, Z. (2020): Egyedül nem megy - fogyatékkal élők utazási szokásainak vizsgálata egy nemzetközi felmérés eredményeinek tükrében. In: Csapó, J. -Csóka, L. (szerk.): Kreativitás, változás, reziliencia. III. Nemzetközi Turizmusmarketing Konferencia: Tanulmánykötet. Pécs, Magyarország: Pécsi Tudományegyetem Közgazdaságtudományi Kar, (2020) pp. 154-165. 12p. ISBN 978-963-429-506-8

KÖNCZEI, GY. - HERNÁDI, I. (2015): A fogyatékosságtudomány „térképei”. In: Hernádi I. Könczei Gy. (szerk.): A felelet kérdései között. Fogyatékosságtudomány Magyarországon. Eötvös Loránd Tudományegyetem Bárczi Gusztáv Gyógypedagógiai Főiskolai Kar, Budapest.

KUHLEN, T. - DOHLE, C. (1995): Virtual reality for physically disabled people. Computers in Biology and Medicine. 25(2) 205-211. DOI: 10.1016/0010-4825(94)00039-S

LONGMIRE, S. (2020): Everything you need to know about wheelchair accessible cruising, Spin the Globe 2020, ISBN 1734511303, 9781734511307 
LOVELOCK, B. A. (2010): Planes, trains and wheelchairs in the bush: Attitudes of people with mobility disabilities to enhanced motorised access in remote natural settings. Tourism Management, 31(3), 357 -366.

McKERCHER, B. et al. (2003). Travel agents as facilitators or inhibitors of travel: Perceptions of people with disabilities. Tourism Management, 24 (2003), pp. 465-74.

PACKER, T. et al. (2006): Understanding the complex interplay between tourism, disability and environmental contexts. FINADAPT Working Paper 11. Finnish Environment Institute, Helsinki. PAGÁN, R. (2012): Time allocation in tourism for people with disabilities. Annals of Tourism Research, 39(3), p. $1514-1537$.

PORIA, Y. et al. (2009): People with disabilities visit art museums: An exploratory study of obstacles and difficulties. Journal of Heritage Tourism, 4(2), 117 - 129.

SMALL, J. - DARCY, S. (2010) Understanding tourist experience through embodiment: the contribution of critical tourism and disability studies. In: Buhalis, D., Darcy, S. and Ambrose, I. (eds.): Accessible Tourism: Concepts and Issues. Channel View, Clevedon, pp. 1-25.

ZSARNÓCZKY, M. (2019): A kompatibilitás fontossága az akadálymentes turizmus speciális szegmensében In: \#Turizmus \#Szálloda \#Vendéglátás. Eger, Eszterházy Károly Egyetem Líceum Kiadó. pp. 173-182.

\section{Egyéb források}

EUROPEAN COMMISSION (2014): Economic Impact and Travel Patterns of Accessible Tourism in Europe - Final Report. Brussels. pp. 24-28.

Manual on Accessible Tourism for All: Principles, Tools and Best Practices Module V: Best Practices in Accessible Tourism, 2016, World Tourism Organization (UNWTO)

MEOSZ 2016 A Mozgáskorlátozottak Egyesületeinek Országos Szövetsége javaslata a turizmusról szóló törvénytervezethez

MTÜ (2017): Akadálymentes turizmus. https:// mtu.gov.hu/cikkek/akadalymentes-turizmus MTÜ (2018): Nemzeti Turizmusfejlesztési Stratégia 2030. Magyar Turisztikai Ügynökség, Budapest.

TOURISM FOR ALL http://www.tourismforall.eu/

UNWTO: Accessible Tourism, https://www.unwto.org/accessibility

World Health Organization (WHO) (1980, 2007). International classification of impairments, disabilities and handicaps. Geneva

FORBES (2017): Planning a Cruise when You have a disability, March 27, 2017. https://www.forbes.com/sites/nextavenue/2017/03/27/planning-a-cruise-when-you-have-a-

disability/\#482e46835bd4

Cruise ship accessibility for Persons with disabilities: https://cruising.org/en-gb/about-theindustry/policy-priorities/cruise-ship-accessibility-for-persons-with-disabilities

A Guide to Accessible River Cruises, December 04, 2019 www.cruisecritic.com

A Guide to Accessible river cruises: 7 Things to consider, February 04, 2019. https://www.rivervoyages.com/advice/are-river-cruises-suitable-for-disabled-passengers/

Access granted: Accommodating special-needs travelers, January 14, 2015 https://www.travelweekly.com/Travel-News/Travel-Agent-Issues/Access-granted

TripAdvisor: https://www.tripadvisor.com/ShowTopic-g1-i10703-k13164713-

Best_Euopean_River_Cruises-Cruises.html 